\title{
Ungulate herbivory on Utah aspen: Assessment of long- term exclosures
}

\author{
CHARLES E. KAY AND DALE L. BARTOS
}

Authors are Natural Resource Policy Associate, Institute of Political Economy and Adjunct Assistant Professor, Department of Political Science, Utah State University, Logan, Utah 84322; and Ecologist, USDA Forest Service, Rocky Mountain Research Station, Logan, Utah 84321.

Abstract

The role of livestock grazing and big-game browsing in the decline of aspen (Populus tremuloides Michx.) in the Intermountain West has long been questioned.All known aspen exclosures $(n=8)$ on the Dixie and Fishlake National Forests in south-central Utah were measured during late summer of 1995 and 1996 to determine aspen stem dynamics, successional status, and understory species composition. Five of the exclosures were of a 3-part design with a total-exclusion portion, a livestockexclusion portion, and a combined-use portion which permitted the effects of deer (Odocoileus hemionus) and elk (Cervus elaphus) herbivory to be measured separately from those of livestock. Aspen within all total-exclusion plots successfully regenerated and developed multi-aged stems without the influence of fire or other disturbance. Aspen subjected to browsing by wildlife, primarily mule deer, either failed to regenerate successfully or regenerated at stem densities significantly lower $(2,498$ stems ha-1) than that on total-exclusion plots $\left(4,474\right.$ stems $\left.^{-1} a^{-1}\right)$. On combined wildlife-livestock-use plots, most aspen failed to regenerate successfully, or did so at low stem densities $\left(1,012 \mathrm{stems}^{-h^{-1}}{ }^{-1}\right)$. Aspen successfully regenerated on ungulate-use plots only when deer numbers were low. Similarly, ungulate herbivory had significant effects on understory species composition. In general, utilization by deer tended to reduce shrubs and tall palatable forbs while favoring the growth of native grasses. The addition of livestock grazing, however, tended to reduce native grasses while promoting introduced species and bare soil. Thus, communities dominated by old-age or single-age trees appear to be a product of ungulate browsing, not a biological attribute of aspen as has been commonly assumed. There was no evidence that climatic variation affected aspen regeneration. Observed differences are attributed to varied histories of ungulate herbivory.

Key Words: Populus tremuloides communities, reproduction, decline, cattle grazing, deer browsing, elk browsing, undergrowth.

Aspen (Populus tremuloides Michx.) in the western United States does not commonly grow from seed because of its demanding seed bed requirements (Kay and White 1995,

\footnotetext{
Research was funded by U.S. Forest Service's Intermountain Research Station (now part of the Rocky Mountain Research Station) and we thank the many agency employees who helped with various aspects of this project, especially Robert B. Campbell, Jr. and Dr. Walter F. Mueggler (Scientist Emeritus). Also, Brad Williams and the Utah State Trust Lands Administration for granting access to their files on the Parker Mountain exclosure.

Manuscript accepted 28 June 1999.
}

\section{Resumen}

El papel del apacentamiento del ganado y el ramoneo de la fauna silvestre mayor en la disminución del "Aspen" (Populus tremuloides Mitch.) en la región intermontañosa del oeste has sido ampliamente cuestionado. A fines de los veranos de 1995 y 1996 se midieron todas las exclusiones conocidas $(n=8)$ de "Aspen" en los Bosques Nacionales Dixie y Fishlake situados en la región surcentral de Utah. Las mediciones realizadas en estas exclusiones fueron para determinar la dinámica de tallos, el estado sucesional y la composición de especies herbáceas. Cinco de las exclusiones estuvieron dentro de un diseño de tres factores: exclusión total, exclusión contra el ganado y uso combinado, el cual permitía medir separadamente los efectos de la herbívora de venados (Odocoielus hemonius) y alces (Cervus elaphus) de la del ganado. El "Aspen" se regeneró exitosamente dentro de las exclusiones, y sin la influencia del fuego u otro factor de disturbio, desarrollo una estructura de tallos de diferentes edades. El "aspen" sujeto al ramoneo de la fauna silvestre, principalmente venado, fallo en regenerarse exitosamente o se desarrollo con densidades de tallos significativamente menores $(2,498$ tallos ha' $)$ que el "aspen de las parcelas totalmente excluidas $\left(4,474\right.$ tallos ha $\left.{ }^{-1}\right)$. En las parcelas de uso combinado, ganado-fauna, la mayoría del aspen no se regeneró satisfactoriamente o lo hizo con bajas densidades de tallos (1,012 tallos ha $\left.{ }^{-1}\right)$. El "Aspen" se regeneró exitosamente en las parcelas utilizadas por ungulados solo cuando el número de venados fue bajo. En forma similar, la herbívora de los ungulados tuvo efectos significativos en la composición del estrato herbáceo. En general, la utilización por el venado tendió a reducir los arbustos y las hierbas altas palatables mientras que favoreció el crecimiento de los zacates nativos. Por otra parte, la adición del apacentamiento de ganado domestico, tendió a reducir los zacates nativos y promovió el desarrollo de especies introducidas y de suelo desnudo. Así, las comunidades dominadas por arboles viejos o de una sola edad parecen ser el producto del ramoneo por los ungulados y no un atributo biológico del "Aspen" como comúnmente se ha asumido. No hubo evidencia de que la variación climática afectara la regeneración del "Aspen". Las diferencias observadas se atribuyeron a diferentes historiales de herbívora de los ungulados.

McDonough 1979). Because individual trees are relatively shortlived ( $<150$ years), long-lived aspen clones are often dependent on periodic disturbance such as fire to stimulate vegetative regeneration via root suckering, and to reduce conifer competition (Bartos and Mueggler 1981, Shepperd and Smith 1993).

Aspen has been declining throughout the Intermountain West since shortly after European settlement (Kay 1997a, Bartos and 


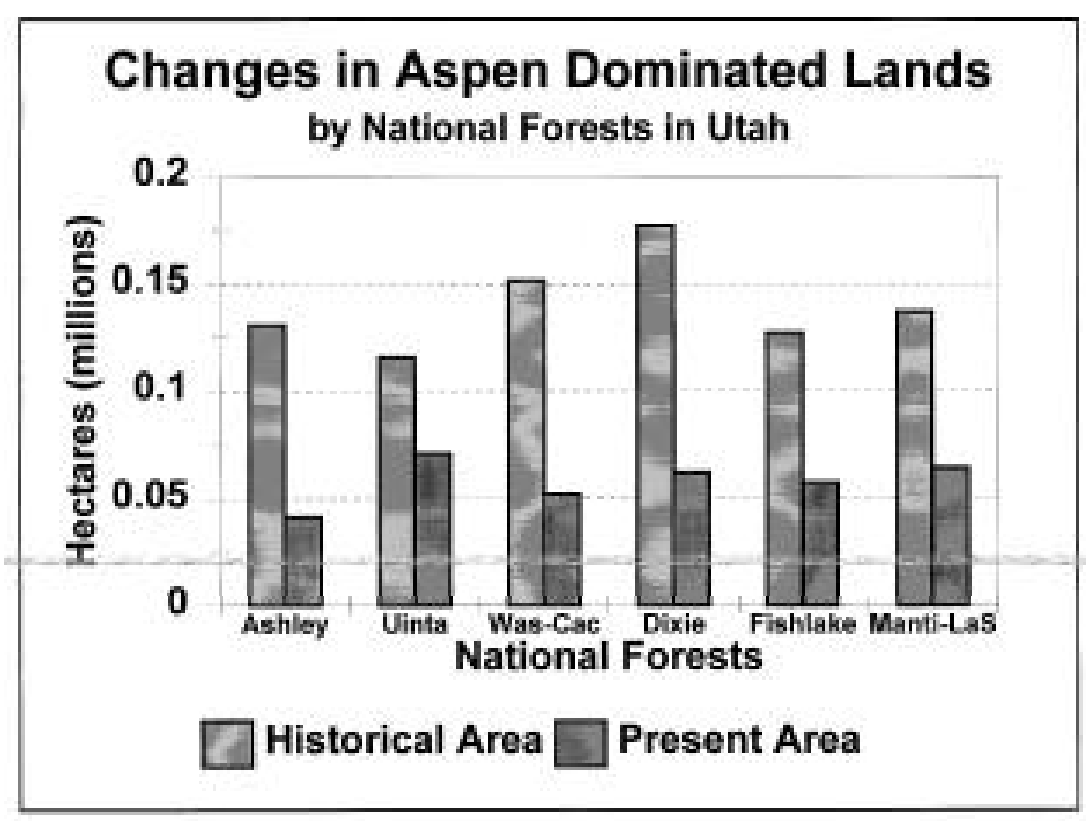

Fig. 1. The decline of aspen on National Forests in Utah. Unpublished forest inventory data, Rocky Mountain Research Station, USDA Forest Service, used with permission.

Campbell 1998). On the Fishlake and Dixie National Forests in Utah, for example, there were historically over 304,000 ha of aspen; today there are only approximately 120,000 ha (Fig. 1). Furthermore, many aspen stands contain old-age or single-age trees and have not successfully regenerated for 80 years or longer (Mueggler 1989).

Several hypotheses have been advanced to explain this decline. These include fire suppression (Houston 1973, Despain et al 1986), climate change (Despain et al. 1986, Romme et al. 1995), livestock grazing (Sampson 1919, Baker 1925), and browsing by mule deer (Odocoileus hemionus) and/or elk (Cervus elaphus) (Olmstead 1979, Shepperd and Fairweather 1994).

To test the ungulate herbivory hypothe- ses, we measured all of the long-term, aspen-containing exclosures on the Fishlake and Dixie National Forests in south-central Utah. These exclosures, established during the 1930s to 1970 s, were built to study the effect of livestock and/or wildlife use on aspen communities (Young 1956, Laycock 1969).

\section{Methods}

Laycock's (1975) list of range reference sites in Utah was first checked for aspencontaining exclosures on the Fishlake and Dixie National Forests. Forest Service employees on both national forests were then contacted to see if these exclosures still existed and if additional aspen-con- taining exclosures were present on the 2 forests. These potential study sites were subsequently field-checked to see if the exclosures were still functional. We tried to locate in agency files all previous vegetation data, written description of permanent vegetation sampling schemes, and any old photographs.

Some of the exclosures were of a 2-part design where an inside area was fenced to exclude livestock, primarily cattle, but deer and elk had access. Adjacent unfenced outside plots were grazed by both wild and domestic ungulates. Other exclosures were of a 3-part design where 1 area was fenced to exclude all ungulates (treatment 1), another was fenced to exclude livestock (treatment 2 ), and outside areas were open to wild and domestic ungulates (treatment 3 ).

At each exclosure, any permanent aspen plots previously established by the agencies were resampled and permanent photopoints rephotographed. Sampling was done during late summer of 1995 and 1996. Next, 2 x 30 m belt transects were placed in representative aspen communities within each of the various parts of each exclosure (Kay 1990). The varied size of exclosures did not always allow sampling with an equal number of transects (Table 1). Each treatment at the following exclosures were sampled by 3 belt transects: Pot Holes, Blind Lake, Riddle Swale, and Hancock. Each treatment on Park Pasture was sampled by 4 transects, and Parker Mountain by 6. At Woodchuck, treatments 1 and 2 were sampled by 3 transects and treatment 3 by 2 ; at Grindstone, treatments 1 and 2 were also sampled by 3 transects, but treatment 3 by 4. To facilitate recording data, each $30 \mathrm{~m}$ transect was subdivided into 3 segments and the number of live aspen stems was recorded using the following size classes within each segment: (1) stems less than 2 $\mathrm{m}$ tall, (2) stems greater than $2 \mathrm{~m}$ tall but

Table 1. Location and description of aspen containing exclosures in south-central Utah, compiled in 1995-1996.

\begin{tabular}{|c|c|c|c|c|c|c|c|c|c|c|}
\hline \multirow{2}{*}{ Exclosure } & \multirow{2}{*}{$\begin{array}{c}\text { Land } \\
\text { Ownership }\end{array}$} & \multicolumn{3}{|c|}{ Location } & \multirow{2}{*}{$\begin{array}{c}\text { Year } \\
\text { established }\end{array}$} & \multicolumn{2}{|c|}{ Size $(\mathrm{m})$} & \multirow[t]{2}{*}{ Elevation } & \multirow{2}{*}{$\begin{array}{c}\text { Main } \\
\text { aspect }\end{array}$} & \multirow{2}{*}{$\begin{array}{c}\text { Vegetation } \\
\text { type }^{2}\end{array}$} \\
\hline & & Township & Range & Section & & $\begin{array}{l}\text { Livestock } \\
\text { exclusion }\end{array}$ & $\begin{array}{l}\text { Total } \\
\text { exclusion }\end{array}$ & & & \\
\hline & & & & & & & & $(\mathrm{m})$ & & \\
\hline Pot Holes & DNF & $30 \mathrm{~S}$ & $3 \mathrm{E}$ & 27 & 1958 & $62 \times 63$ & None & 2743 & NW & $\mathrm{A}, \mathrm{S} / \mathrm{G}$ \\
\hline Park Pasture & DNF & $31 \mathrm{~S}$ & $5 \mathrm{E}$ & 22 & 1957 & $88 \times 94$ & None & 2652 & $\mathrm{NE}$ & $\mathrm{A}, \mathrm{G}$ \\
\hline Blind Lake & DNF & $30 \mathrm{~S}$ & $4 \mathrm{E}$ & 24 & 1958 & $44 \times 117$ & None & 2984 & SE & $\mathrm{A}, \mathrm{G}$ \\
\hline Riddle Swale & DNF & $33 \mathrm{~S}$ & $1 \mathrm{~W}$ & 19 & 1957 & $65 \times 76$ & $65 \times 113$ & 2554 & $\mathrm{~N}$ & $\mathrm{~A}, \mathrm{~S} / \mathrm{G}, \mathrm{C}$ \\
\hline Woodchuck & DNF & $31 \mathrm{~S}$ & $21 / 2 \mathrm{~W}$ & 33 & 1947 & $63 \times 63$ & $63 \times 63$ & 2804 & $\mathrm{~S}$ & $\mathrm{~A}, \mathrm{~S} / \mathrm{G}$ \\
\hline Grindstone & FNF & $29 \mathrm{~S}$ & $4 \mathrm{~W}$ & 29 & 1934 & $46 \times 63$ & $46 \times 63$ & 2816 & $\mathrm{~S}$ & $\mathrm{~A}, \mathrm{C}$ \\
\hline Hancock & FNF & $26 \mathrm{~S}$ & $1 \mathrm{E}$ & 11 & 1962 & $61 \times 61$ & $61 \times 61$ & 3054 & SE & $\mathrm{A}, \mathrm{C}$ \\
\hline Parker Mountain & UT & $28 \mathrm{~S}$ & $1 \mathrm{~W}$ & 26 & 1974 & $100 \times 100$ & $100 \times 100$ & 2804 & $\mathrm{E}$ & $\mathrm{A}, \mathrm{S} / \mathrm{G}$ \\
\hline
\end{tabular}

${ }^{\mathrm{D}} \mathrm{DNF}$ = Dixie National Forest, FNF = Fishlake National Forest, UT= Utah State School Trust Lands.

${ }^{2}$ Vegetation types within the exclosures. $\mathrm{A}=$ aspen, $\mathrm{S} / \mathrm{G}=$ sagebrush/grasslands, $\mathrm{G}=$ grasslands, and $\mathrm{C}=$ conifers 
less than $5 \mathrm{~cm}$ diameter at breast height (DBH), (3) stems between 6 and $10 \mathrm{~cm}$ DBH, (4) stems between 11 and $20 \mathrm{~cm}$ $\mathrm{DBH}$, and (5) stems greater than $21 \mathrm{~cm}$ DBH. Ages of aspen within each size class were determined by coring the larger and cutting the smaller stems and counting annual rings.

The number and species of conifers were recorded on the $2 \times 30 \mathrm{~m}$ belt transects using the same size classes. While a $2 \times 30 \mathrm{~m}$ belt transect is adequate to measure aspen stem dynamics and conifer seedlings (Bartos et al. 1994), a plot of that size tends to underestimate the more widely spaced conifers. To overcome this problem, the total percent conifer canopy cover was estimated in each aspen stand following Mueggler (1988).

Aspen and conifer stem counts on each of the $2 \times 30 \mathrm{~m}$ belt transects were used to produce a mean number of stems per hectare by size classes for each treatment at each site. The treatment means of the various aspen size class data were then compared using repeated measures analysis of variance. Each site was considered an experimental unit for this analysis.

Frequency and canopy-cover of understory plants, bare soil, and rock were recorded from $0.1 \mathrm{~m}^{2}$ plots at $1 \mathrm{~m}$ intervals to the right of each of the belt-transect's centerline (Daubenmire 1959). Readings from all the $0.1 \mathrm{~m}^{2}$ understory plots were averaged within each treatment and then compared using Student's t-test.

Other information recorded at each study site included: Universal Mercator Grid coordinates, elevation, aspect, old and new bark damage, highlining, and sucker browsing. The last 3 items provided an estimate of past ungulate use. Elk and moose (Alces alces) strip-off and eat the bark of aspen. Such bark damage usually occurs during winter when other foods are in short supply. Mule deer do not strip aspen bark, but mule deer, elk, and moose all browse aspen when the plants are available.

To determine the effects of deer herbivory on Indian paintbrush (Castilleja miniata Dougl.) we measured the height, crown diameter, total number of flower stalks, and the number of grazed flower stalks. These measurements were made just at the Hancock site.

\section{Results}

Many of the aspen-containing exclosures listed by Laycock (1969) for southcentral Utah no longer exist or were not maintained. Thus, only 8 exclosures containing aspen were evaluated (Table 1). Prior data were found for the Grindstone Flat exclosure. Photographs showing the originally enclosed aspen communities were found for 4 exclosures (Pot Holes, Park Pasture, Grindstone Flat, and Parker Mountain).

\section{Pot Holes}

With protection from cattle grazing, the aspen stand successfully established new stems without fire or other disturbance, and increased in size inside the exclosure as evidenced by photographs. The new suckers established in the early 1970s when mule deer numbers were low (Fig. 2). Later when deer numbers expanded the animals consumed all the lower branches from the newly grown aspen, termed highlining, and prevented new suckers from exceeding $1 \mathrm{~m}$ in height. The aspen stand inside the exclosure is now composed of

Table 2. Mean aspen stem densities by size classes and estimated conifer canopy cover inside and outside exclosures in south-central Utah in 1995-96.

\begin{tabular}{|c|c|c|c|c|c|c|}
\hline \multirow[b]{2}{*}{ Exclosure } & \multicolumn{4}{|c|}{ Mean aspen stem density by size classes } & & \multirow{2}{*}{$\begin{array}{c}\text { Conifer } \\
\text { canopy } \\
\text { cover }\end{array}$} \\
\hline & $<2 \mathrm{~m}$ tall & $\begin{array}{l}2 \mathrm{~m} \text { tall to } \\
5 \mathrm{~cm} \mathrm{DBH}\end{array}$ & $\begin{array}{l}6 \text { to } 10 \mathrm{~cm} \\
\text { DBH }\end{array}$ & $\begin{array}{l}11 \text { to } 20 \mathrm{~cm} \\
\text { DBH }\end{array}$ & $\begin{array}{l}>20 \mathrm{~cm} \\
\mathrm{DBH}\end{array}$ & \\
\hline & \multicolumn{5}{|c|}{ 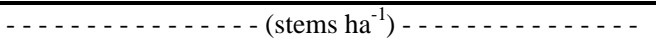 } & $(\%)$ \\
\hline \multicolumn{7}{|c|}{ 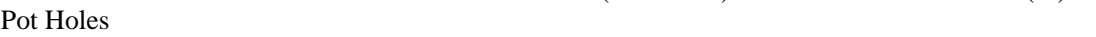 } \\
\hline Livestock exclusion & 7,348 & 3,791 & 2,221 & 618 & 333 & $<1$ \\
\hline Outside & 9,018 & 668 & 0 & 55 & 55 & $<1$ \\
\hline \multicolumn{7}{|l|}{ Park Pasture } \\
\hline Livestock exclusion & 1,221 & 4,676 & 3,758 & 1,378 & 250 & $<1$ \\
\hline Outside & 459 & 835 & 835 & 0 & 584 & $<1$ \\
\hline \multicolumn{7}{|l|}{ Blind Lake } \\
\hline Livestock exclusion & 9,574 & 8,684 & 3,228 & 1,057 & 556 & $<1$ \\
\hline Outside & 8,963 & 6,568 & 167 & 55 & 668 & $<1$ \\
\hline \multicolumn{7}{|l|}{ Riddle Swale } \\
\hline Total exclusion & 7,228 & 4,670 & 2,780 & 1,890 & 168 & $<1$ \\
\hline Livestock exclusion & 8,613 & 2,446 & 834 & 0 & 449 & $<1$ \\
\hline Outside & 1,890 & 0 & 111 & 0 & 222 & 5 \\
\hline \multicolumn{7}{|l|}{ Woodchuck } \\
\hline Total exclusion & 5,177 & 4,787 & 2,394 & 1,169 & 390 & None \\
\hline Livestock exclusion & 946 & 0 & 56 & 779 & 390 & None \\
\hline Outside & 2,088 & 0 & 0 & 1,086 & 0 & None \\
\hline \multicolumn{7}{|l|}{ Grindstone Flat } \\
\hline Total exclusion & $\mathrm{NA}^{1}$ & 2,505 & 3,396 & 1,614 & 333 & 30 \\
\hline Livestock exclusion & NA & 0 & 222 & 835 & 668 & 50 \\
\hline Outside & NA & 0 & 0 & 167 & 752 & 60 \\
\hline \multicolumn{7}{|l|}{ Hancock } \\
\hline Total exclusion & 5,288 & 7,738 & 1,225 & 557 & 445 & 11 \\
\hline Livestock exclusion & 2,728 & 0 & 0 & 0 & 557 & 31 \\
\hline Outside & 4,676 & 0 & 0 & 0 & 500 & 30 \\
\hline \multicolumn{7}{|l|}{ Parker Mountain } \\
\hline Total exclusion & 974 & 2,672 & 1,308 & 84 & 500 & None \\
\hline Livestock exclusion & 4,509 & 389 & 0 & 0 & 84 & None \\
\hline Outside & 1,030 & 28 & 0 & 0 & 306 & None \\
\hline \multicolumn{7}{|l|}{ Means } \\
\hline Total Exclusion & $4,668 \mathrm{a}^{2}$ & $4,474 \mathrm{a}$ & $2,221 \mathrm{a}$ & $1,063 \mathrm{a}$ & $734 a$ & - \\
\hline Livestock Exclusion & $4,991 \mathrm{a}$ & $2,498 b$ & $1,289 \mathrm{ab}$ & $583 a$ & $822 \mathrm{a}$ & - \\
\hline Outside & $4,018 \mathrm{a}$ & $1,012 b$ & $139 b$ & $170 \mathrm{a}$ & $772 \mathrm{a}$ & - \\
\hline
\end{tabular}

NA $=$ Stems less than $2 \mathrm{~m}$ tall were not counted because most had been consumed by a recent fire - see text.

${ }^{2}$ Means within columns followed by the same letter are not different at $\mathrm{P}<0.08$ by analysis of variance on means. 
stock had been excluded, while Antennaria microphylla Rydb. was more prevalent outside the exclosure. There was also more bare soil and less litter outside the exclosure than inside.

\section{Park Pasture}

When the Park Pasture exclosure was erected on the east side of Boulder Mountain, the area was a heavily used sheep-cattle allotment. Sheep were eliminated in 1963 and cattle herbivory subsequently reduced (U.S. Forest Service 1995). Historically, the area was also grazed by high numbers of mule deer, but that herd has since declined (Fig. 2). When the exclosure was built elk were rare, but they are now common. In fact, several fresh elk beds were observed inside the exclosure when the site was visited during August 1995.

There were no young aspen stems in 1957, but with exclusion of livestock, aspen regenerated and spread inside the exclosure (Fig. 3). This exclosure is also on an aspen-grassland ecotone with few conifers. Ponderosa pine, Douglas-fir, spruce (Picea spp. A. Dietr.), and subalpine fir (Abies lasiocarpa (Hook.) Nutt.) are the most common species in the immediate area. The largest aspen were 38-40 cm DBH and were $105-115$ years old. Inside the exclosure there were numerous $10-15 \mathrm{~cm}$ DBH stems that were 25-30 years old, but there were none outside (Table 2). These began growth during the mid-1960's when combined high deer and cattle grazing apparently prevented aspen regeneration outside the exclosure. When deer numbers declined during the early to mid-1970s (Fig. 2), aspen regenerated both inside and outside the exclosure, but trees were about 5-times more numerous where cattle also were excluded (Table 2). The 6-10 cm DBH stems were all approximately 20 years old. Rebounding deer populations during the 1980s highlined the regenerated aspen and prevented new suckers from growing taller. Little difference, however, existed in understory species composition or frequency.

\section{Blind Lake}

The Blind Lake exclosure on the north side of Boulder Mountain is in an area comprised primarily of aspen and small meadows. Aspen stems inside the exclosure are multi-sized and multi-aged, and began regenerating shortly after the exclosure was erected (Table 2). The elimination of cattle grazing reduced browsing on the aspen suckers and allowed them to grow into the larger size classes. Aspen

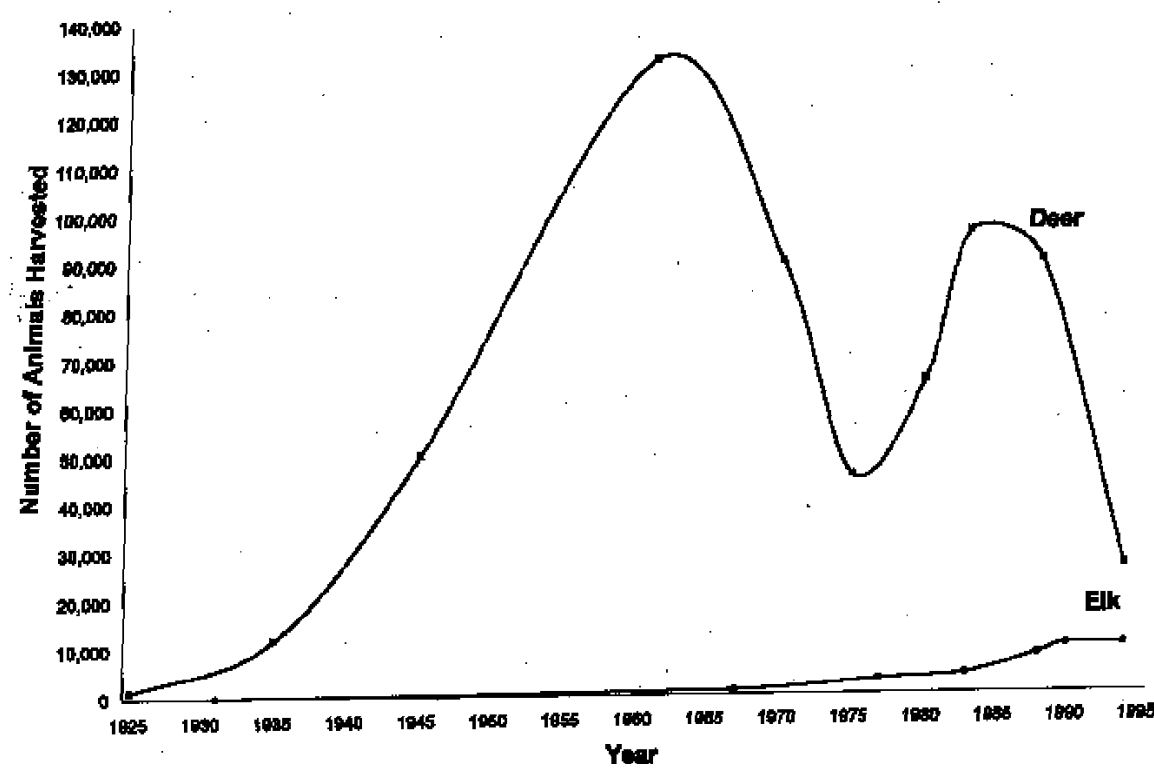

Fig. 2. The number of deer and elk harvested by hunters in Utah from 1925 to 1995. (Utah Div. of Wildlife Resources' Annual big Game Reports-data smoothed to show historical trends.)

outside the exclosure regenerated approximately 20 years ago when deer populations plummeted (Fig. 2), despite continued access by cattle. The largest aspen were $30-38 \mathrm{~cm} \mathrm{DBH}$ and $95-105$ years old, while the $4-5 \mathrm{~cm}$ DBH stems were 18-25 years of age. Photographic evidence indicates that the aspen clone inside the exclosure has increased in area displacing a largely grassland community.

There was significantly less snowberry (Symphoricarpos oreophilus Gray) $(\mathrm{P}<0.01)$ and lovage (Ligusticum porteri Coult. \& Rose) $(\mathrm{P}<0.01)$, and significantly more bare soil $(\mathrm{P}<0.01)$ and dandelion (Taraxacum officinale Weber ex Wiggers) outside the exclosure. In general, there were more palatable forbs (U.S. Forest Service 1937, Nelson and Leege 1982, Wallmo and Regelin 1981) inside than outside the exclosure, while less palatable and non-native forbs were more common outside than inside. There was also more vegetative cover inside than outside the exclosure $(\mathrm{P}<0.01)$.

\section{Riddle Swale}

Riddle Swale is a 3-part exclosure with a total-exclusion portion, a livestockexclusion portion, and an outside plot open to both wildlife and cattle. The site is located on the west side of Escalante Mountain at the ecotone between aspen, sagebrush, and pinyon-juniper. A few Utah juniper (Juniperus osteosperma (Torr.) Little), pinyon pine (Pinus mono phylla Torr. \& Frem. In Frem.), ponderosa pine, and Douglas-fir are found both inside and outside the exclosure.
Inside the total-exclusion part aspen began regenerating shortly after the exclosure was constructed in 1957; the stems are now multi-sized and multi-aged (Table 2 ). In the livestock-exclusion portion of the exclosure, aspen only regenerated when deer numbers declined around 20 years ago (Fig.2). As the deer recovered, however, they highlined all the previous aspen regeneration inside the livestock exclosure and prevented any new aspen suckers from growing more than $1 \mathrm{~m}$ tall. Where both cattle and deer grazed, few aspen stems attained more than $2 \mathrm{~m}$ in height (Table 2). The largest aspen at this site were $23-26 \mathrm{~cm} \mathrm{DBH}$ and $72-78$ years old. The $8-10 \mathrm{~cm}$ DBH stems were $20-25$ years old, and the $3-5 \mathrm{~cm}$ stems were 14-20 years old.

There were also major differences in understory species composition. Deer use only and combined use eliminated Indian paintbrush, while combined big game and cattle use significantly $(\mathrm{P}<0.01)$ reduced the canopy cover of native grasses compared to the exclosures. Conversely, sagebrush increased under deer use, but more so under combined use. Bare soil and rock were not apparent where ungulate herbivory was absent, but increased to $6.4 \%$ cover where only wildlife grazed and to $27.2 \%$ cover with combined deer-cattle use $(\mathrm{P}<0.01)$.

\section{Woodchuck}

Woodchuck is a 3-way exclosure built on the northeast slope of Mount Dutton. Although this exclosure is at over $2,800 \mathrm{~m}$ 

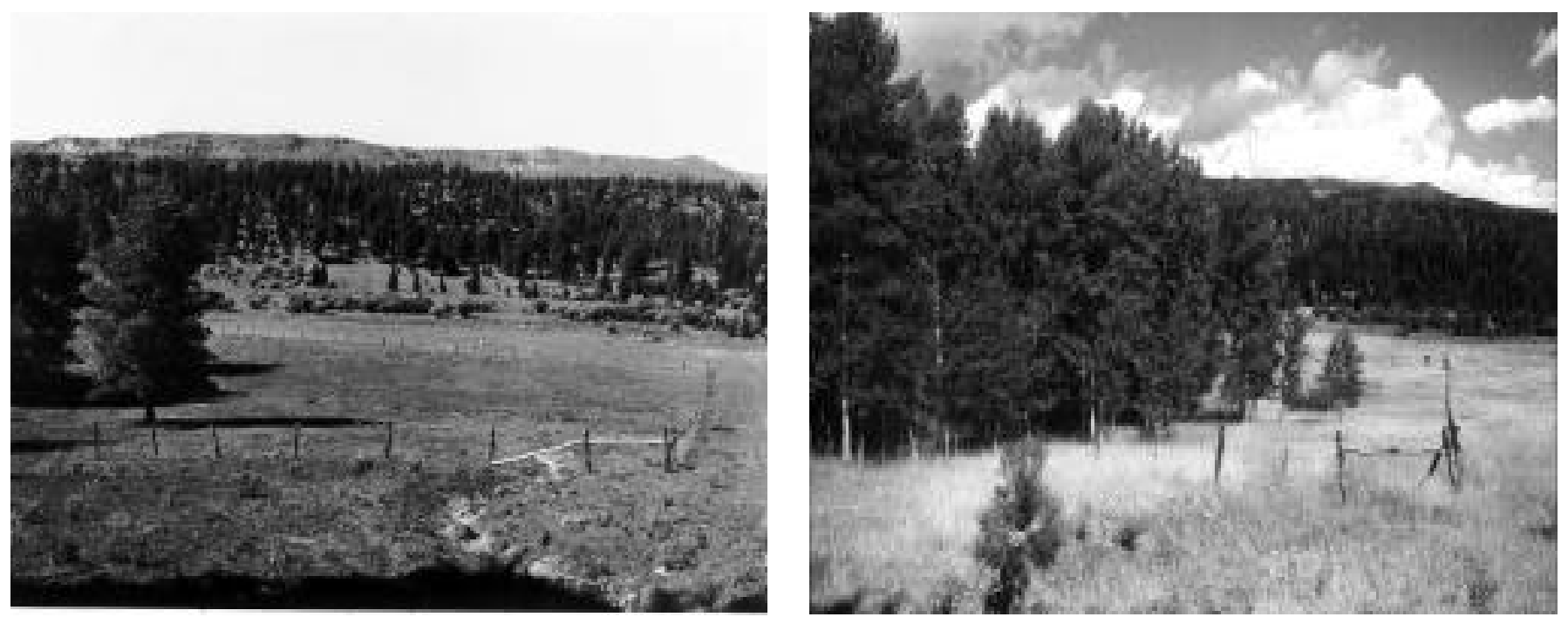

Fig. 3. Photographs of the Park Pasture exclosure: (a) taken in September 1958 shortly after the exclosure was constructed and showing no aspen regeneration; and (b) in August 1995 showing spread of aspen inside the exclosure.

in elevation, it is surrounded by extensive sagebrush-grasslands and lacks conifers. Cattle have used this allotment historically, and deer numbers have also been high. Elk have recently become common on Mount Dutton but do not appear to use this isolated patch of aspen.

Aspen within the total-exclusion part is multi-sized and multi-aged (Table 2), and began regenerating shortly after the exclosure was constructed in 1947. No new aspen stems have attained heights of $2 \mathrm{~m}$ or more in the livestock-exclusion or combined-use areas. The deer at this site have not allowed aspen to regenerate even where cattle have been excluded. The largest aspen were 25-30 cm DBH and 100+ years old, while aspen in the $15-16 \mathrm{~cm}$ size class were 65-70 years of age. Apparently, some event in the late 1920 s and early 1930 s allowed some aspen regeneration in this stand before it was enclosed.

Deer use significantly reduced wild rose (Rosa woodsii Lindl.), snowberry, lupine (Lupinus caudatus Kellogg), and Indian paintbrush, but favored the growth of native grasses, especially needle and thread (all $\mathrm{P}<0.01$ ). The addition of cattle grazing significantly reduced native grass cover $(<0.01)$ and significantly increased the amount of bare soil $(\mathrm{P}<0.01)$. The canopy cover of introduced Kentucky bluegrass (Poa pratensis L.) increased from $1.9 \%$ in the total exclusion area, to $23.7 \%$ under deer only use $(\mathrm{P}<0.01)$, and to $50.9 \%$ with the addition of cattle grazing $(\mathrm{P}<0.01)$. Total vegetative understory cover declined significantly $(\mathrm{P}<0.01)$ from $95.9 \%$ in the non-grazed area to $77.7 \%$ in the wildlife only area to $63.7 \%$ with combined use.

\section{Grindstone Flat}

The 3-part exclosure at Grindstone Flat (Table 1) was evaluated during the 1950s (Young 1956), and then remeasured by the U.S. Forest Service in 1975 (Mueggler and Bartos 1977). Part of the site was originally clear-cut prior to exclosure construction, but $1 / 3$ of each exclosure, as well as all of the outside aspen, were left uncut. Only the uncut areas were analyzed to maintain comparability with the other sites.

Aspen regenerated inside the totalexclusion area, while deer use prevented aspen regrowth in the livestock-exclusion area, as well as the outside area (Table 2). Spruce and subalpine fir have heavily invaded the area (Mueggler and Bartos 1977)

During late June 1996 the exclosure and much of the surrounding lands were burned by the Pole Creek wildfire. Much of the vegetation inside the exclosure complex was burned, and the old exclosure pole-fence destroyed. The total-exclusion and livestock-exclusion areas were completely consumed by flames, as was the surrounding outside aspen. In contrast, the cut total-exclusion area was largely unburned while the cut livestock-exclusion area did not burn at all.

Since this is 1 of only 2 long-term exclosures on the Fishlake National Forest containing aspen, the Forest Service rebuilt the exclosure fences in 1997 . We were able to measure aspen stem densities in September 1996 because the largersized live stems were too green to be consumed by the fire. Aspen stems less than 2 $\mathrm{m}$ tall, however, were not quantified because many of those were removed by the fire. Understory species composition was not measured for the same reason.

Of most relevance in this exclosure comparison is that aspen in the totalexclusion area successfully regenerated and produced a multi-aged stand prior to the 1996 fire, while aspen in the livestock exclosure and outside combined use areas produced no new stems greater than $2 \mathrm{~m}$ tall. Conifer cover in the total-exclusion area was less than in the areas accessible to either deer or cattle (Table 2).

The largest aspen trees were $38-44 \mathrm{~cm}$ DBH, but age determination was difficult because of extensive heart rot. In 1975 , Mueggler and Bartos (1977) recorded a 41 cm DBH aspen that was 175 years old, so the few remaining, unburned trees were likely approaching or near the maximum age (200 years) recorded for aspen in the Intermountain West (Jones and Schier 1985).

\section{Hancock}

This 3-part exclosure is located above Doctor Canyon, approximately $3 \mathrm{~km}$ southeast of Hancock Flat and $1 \mathrm{~km}$ northeast of Rust Spring. Unlike the other exclosures in this study, Hancock has been a sheep allotment and mule deer were the most abundant wild ungulate.

Aspen in the total-exclusion portion began regenerating shortly after the exclosure was constructed and today is multisized and multi-aged despite invasion by conifers (Table 2). Aspen has not regenerated successfully in either the wildlifeonly or the combined-use areas; all of the aspen suckers that occur have been repeatedly browsed by deer and/or sheep. When this site was measured in July, mule deer 
had already browsed many of the new aspen suckers in the livestock-exclusion portion of the exclosure. The largest aspen stems were $30 \mathrm{~cm} \mathrm{DBH}$ and $105+$ years old. Spruce canopy cover appeared greater on the grazed portion than on the ungrazed portion of the exclosure.

Deer grazing and combined use created major differences in understory species composition. Both deer grazing and combined use significantly $(\mathrm{P}<0.01)$ reduced Indian paintbrush, dandelion, and total vegetative cover, and significantly $(\mathrm{P}<0.01)$ increased cover of grass, yarrow (Achillea millefolium L.), rock, bare soil, and litter. Deer grazing also significantly $(\mathrm{P}<0.01)$ reduced height, crown diameter, and number of flower stalks of individual Indian paintbrush plants. Deer had already grazed $63 \%$ of the Indian paintbrush flower stalks inside the livestock-exclusion portion of this exclosure when it was sampled in July.

\section{Parker Mountain}

When this site was fenced (1974) there was concern that browsing by jackrabbits (Lepus spp.) might effect aspen regeneration. To monitor this, each of the totalexclusion and livestock-exclusion areas were partitioned with additional fencing to prevent entry by lagomorphs on half of these areas.

The exclosure is on a joint cattle-sheep allotment where mule deer and antelope (Antilocapra americana) have been abundant. In recent years, however, the deer population has declined and most of the present wildlife use is by elk. The exclosures are also near the lower elevation of aspen and the site is surrounded by sagebrush-grasslands.

Exclusion of lagomorphs had no effect on aspen regeneration or understory composition so the 2 data sets were pooled. When protected from ungulates, aspen successfully regenerated on this site producing a multi-aged stand (Table 2). Aspen successfully regenerated in the livestock-exclusion part and on outside plots, especially after deer declined, but at significantly lower $(\mathrm{P}<0.05)$ densities than on the total exclusion plot. The increasing elk population, however, highlined those stems and inflicted extensive bark damage (Krebill 1972) on the unprotected aspen. The largest aspen were 26-28 cm DBH and 90-95 years of age. Photographic evidence indicates that aspen in the totalexclusion part of this exclosure has spread into sagebrush-grasslands, an indication that climate had not limited expansion at this site.
Although this exclosure had been in place for only 22 years, there were significant $(\mathrm{P}<0.05)$ differences in understory species composition. Indian paintbrush and littleflower penstemon (Penstemon pro cerus Dougl. ex Graham) had greater frequency and canopy cover in the totalexclusion area than on the wildlife exclusion area, and they were virtually eliminated by combined wildlife-livestock use. Conversely, native grasses were most abundant in the total-exclusion part (54\%), were halved by wildlife-only use, and reduced to only $16 \%$ under combined use. The addition of livestock grazing also increased $(\mathrm{P}<0.05)$ the amount of bare soil.

\section{Discussion}

\section{Aspen Stem Dynamics}

Aspen within all total-exclusion exclosures regenerated successfully without disturbance and developed multi-sized, multiaged stems, even where the stand had been heavily invaded by conifers (i.e., the Hancock exclosure). Aspen subjected to browsing only by wildlife, primarily mule deer, either failed to produce new stems greater than $2 \mathrm{~m}$ tall, or regenerated at stem densities lower than on the totalexclusion plots. On combined wildlifelivestock use plots, most aspen failed to regenerate successfully, or did so at stem densities lower than on the livestockexclusion plots. Aspen regenerated successfully on livestock-exclosed and combined-use plots only when mule deer pop- ulations were low.

Mule deer have been the most prevalent wild herbivore in south-central Utah since at least the 1930s. Moose were only recently transplanted into the area, and elk populations were very low until the 1980s. Deer numbers in Utah generally peaked during the early 1960s, but declined precipitously by 1975 (Fig. 2). This reduced the browsing pressure on aspen suckers, and many stands in southern Utah were able to regenerate successfully if livestock use was not excessive. An increase in deer during the 1980s prevented new aspen suckers from increasing in height, and the deer also consumed the lower branches from aspen that had regenerated earlier (Fig. 4). In the mid-1990s, mule deer populations again declined, but few aspen stands were able to regenerate successfully because increasing numbers of elk were foraging on the young suckers (Fig. 2). Thus, in some areas of Utah, deer browsing has been replaced by elk browsing. Elk also seem to have a greater preference for aspen than mule deer (Kay 1997b, Shepperd and Fairweather 1994). Episodes of aspen regeneration have been observed in other areas when mule deer (Julander and Low 1976, Olmstead 1979) or elk (Olmstead 1979, Kay and White 1995) numbers were low.

\section{Understory Species Composition}

Understory species composition of aspen stands was significantly affected by ungulate herbivory. In general, utilization by mule deer tended to eliminate palatable

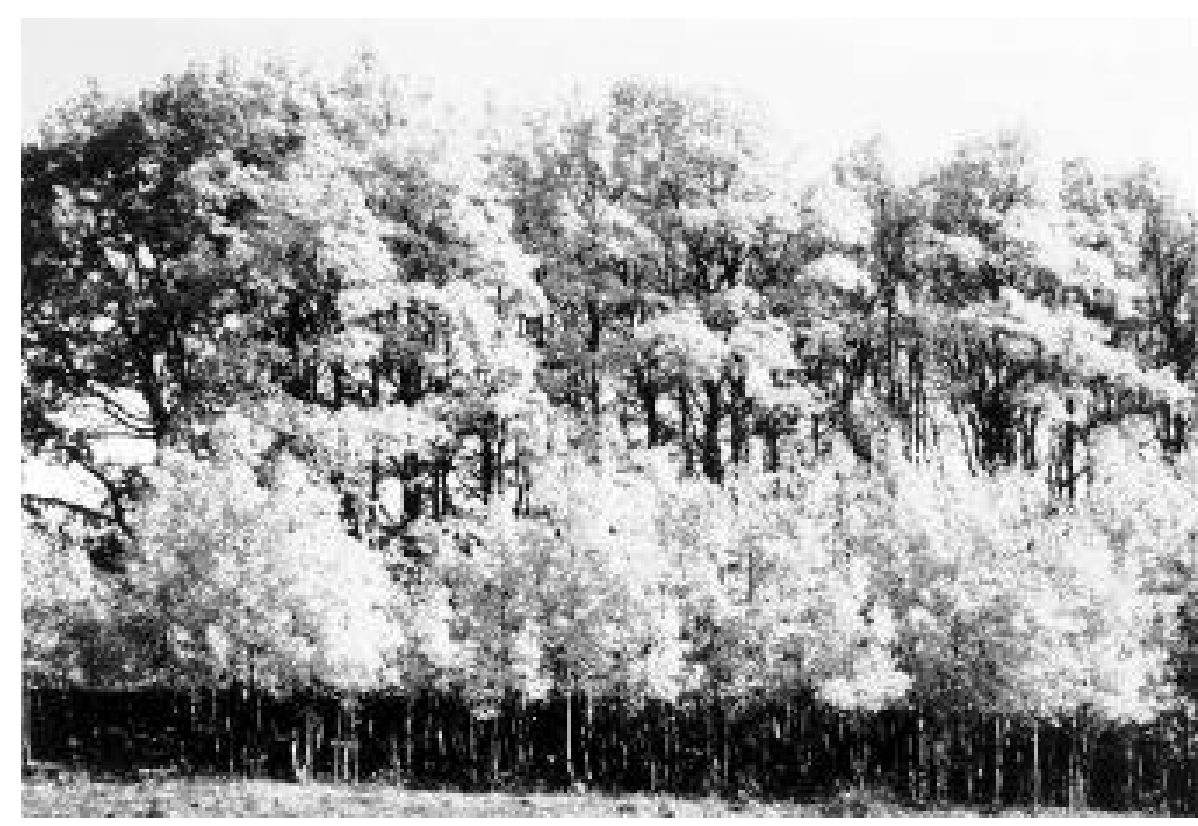

Fig. 4. Highlining by mule deer in a 2-age class aspen stand on the Dixie National Forest. 
Table 3. Mean frequency (Freq.) and canopy cover (C.C.) of undergrowth species on total-exclusion (wild \& domestic ungulates), partial exclusion (livestock), and no-exclusion plots. (Means are based on only those sites where the species occurred; "n" = number of sites where species occurred; summation of cover values therefore are meaningless.)

\begin{tabular}{|c|c|c|c|c|c|c|c|c|c|}
\hline & \multicolumn{3}{|c|}{ TOTAL EXCLUSION } & \multicolumn{3}{|c|}{ PARTIAL EXCLUSION } & \multicolumn{3}{|c|}{ NO EXCLUSION } \\
\hline & $\mathrm{n}$ & Freq. & C.C. & $\mathrm{n}$ & Freq. & C.C. & $\mathrm{n}$ & Freq. & C.C. \\
\hline & \multicolumn{3}{|c|}{$\ldots-\ldots(\%) \ldots$} & \multicolumn{3}{|c|}{$\ldots-\ldots(\%)-\ldots$} & \multicolumn{3}{|c|}{$\ldots-\ldots(\%)-\ldots$} \\
\hline TREES & & & & & & & & & \\
\hline Picea engelmannii Parry ex Engelm. & 1 & 18 & 10.6 & 2 & 45 & 30.3 & 2 & 23 & 14.8 \\
\hline \multicolumn{10}{|l|}{ SHRUBS } \\
\hline Artemisia tridentata Nutt. & 3 & 20 & 7.7 & 4 & 24 & 12.2 & 4 & 25 & 11.3 \\
\hline Artemisia tripartita $\mathrm{Rydb}$. & 1 & 3 & 0.4 & 2 & 2 & 0.2 & 2 & 15 & 4.5 \\
\hline Chrysothamnus nauseosus (Pallas) Britt. & 1 & 1 & 0.1 & 2 & 4 & 1.1 & 2 & 8 & 2.1 \\
\hline Chrysothamnus viscidiflorus (Hook.) Nutt. & 1 & 0 & 0.0 & 2 & 15 & 4.8 & 2 & 20 & 8.1 \\
\hline Juniperus communis L. & 0 & 0 & 0 & 1 & 0 & 0.0 & 1 & 1 & 0.4 \\
\hline Juniperus osteosperma (Torr.) Little & 1 & 7 & 3.3 & 1 & 0 & 0.0 & 1 & 8 & 5.9 \\
\hline Potentilla fruticosa $\mathrm{L}$. & 0 & 0 & 0 & 1 & 4 & 0.3 & 1 & 5 & 0.7 \\
\hline Purshia tridentata (Pursh) DC. & 1 & 0 & 0.0 & 1 & 0 & 0.0 & 1 & 2 & 1.9 \\
\hline Ribes spp. L. & 0 & 0 & 0 & 1 & 8 & 2.9 & 1 & 4 & 1.4 \\
\hline Rosa woodsii Lindl. & 3 & 2 & 0.9 & 4 & 3 & 0.8 & 4 & 4 & 0.8 \\
\hline Symphoricarpos oreophilus Gray & 3 & 17 & 8.0 & 5 & 19 & 8.4 & 5 & 11 & 3.3 \\
\hline \multicolumn{10}{|l|}{ GRAMINOIDS } \\
\hline Agropyron caninum (L.) Beauv. & 3 & 28 & 4.0 & 3 & 16 & 2.4 & 3 & 8 & 0.7 \\
\hline Bromus ciliatus L. & 4 & 28 & 5.6 & 6 & 15 & 1.7 & 6 & 10 & 1.0 \\
\hline Carex spp. L. & 2 & 18 & 0.1 & 1 & 17 & 4.2 & 1 & 0 & 0.0 \\
\hline Festuca idahoensis Elmer & 2 & 1 & 0.1 & 3 & 42 & 9.7 & 3 & 39 & 6.5 \\
\hline Festuca thurberi Vasey & 2 & 40 & 13.4 & 4 & 23 & 5.2 & 4 & 31 & 6.2 \\
\hline Koeleria cristata (L.) Pers. & 1 & 4 & 0.5 & 1 & 35 & 4.2 & 1 & 24 & 2.6 \\
\hline Muhlenbergia wrightii Vasey ex Coult. & 0 & 0 & 0 & 2 & 1 & 0.1 & 2 & 16 & 3.4 \\
\hline Poa interior $(\mathrm{NY})$ & 1 & 7 & 1.1 & 1 & 0 & 0.0 & 1 & 8 & 0.8 \\
\hline Poa pratensis L. & 2 & 8 & 2.8 & 4 & 22 & 15.4 & 4 & 42 & 18.8 \\
\hline Sitanion hystrix (Nutt.) J. G. Sm. & 3 & 18 & 2.6 & 5 & 19 & 3.0 & 5 & 18 & 2.5 \\
\hline Stipa columbiana Macoun & 1 & 4 & 1.8 & 1 & 0 & 0.0 & 1 & 0 & 0.0 \\
\hline Stipa comata Trin. \& Rupr. & 3 & 42 & 11.7 & 6 & 46 & 14.1 & 6 & 30 & 4.1 \\
\hline Stipa lettermanii Vasey & 1 & 17 & 2.3 & 1 & 11 & 2.2 & 1 & 0 & 0.0 \\
\hline \multicolumn{10}{|l|}{ FORBS } \\
\hline Achillea millefolium $\mathrm{L}$. & 2 & 10 & 0.8 & 3 & 34 & 2.7 & 3 & 25 & 14.6 \\
\hline Antennaria microphylla $\mathrm{Rydb}$. & 0 & 0 & 0 & 1 & 0 & 0 & 1 & 54 & 11.9 \\
\hline Aquilegia coerulea James & 1 & 8 & 2.3 & 1 & 3 & 0.2 & 1 & 0 & 0 \\
\hline Aster spp. L. & 1 & 13 & 2.4 & 1 & 9 & 0.9 & 1 & 9 & 0.7 \\
\hline Castilleja linariaefolia Benth. & 3 & 28 & 3.9 & 4 & 6 & 1.1 & 4 & 1 & 0.1 \\
\hline Castilleja miniata Dougl. ex Hook. & 1 & 56 & 29.5 & 1 & 6 & 0.4 & 1 & 2 & 0.2 \\
\hline Fragaria virginiana Duchesne & 0 & 0 & 0 & 1 & 16 & 1.2 & 1 & 3 & 0.2 \\
\hline Galium spp. L. & 1 & 38 & 3.9 & 1 & 28 & 3.6 & 1 & 0 & 0.0 \\
\hline Ligusticum porteri Coult. \& Rose & 0 & 0 & 0 & 2 & 42 & 12.3 & 1 & 0 & 0.0 \\
\hline Lupinus argenteus Pursh & 1 & 37 & 14.2 & 2 & 6 & 1.5 & 2 & 29 & 6.7 \\
\hline Lupinus caudatus Kellogg & 1 & 82 & 40.4 & 1 & 0 & 0.0 & 2 & 18 & 4.4 \\
\hline Penstemon procerus Dougl. ex Graham & 1 & 18 & 3.7 & 1 & 0 & 0.0 & 1 & 0 & 0.0 \\
\hline Phlox spp. L. & 1 & 0 & 0.0 & 1 & 22 & 4.3 & 1 & 6 & 1.2 \\
\hline Potentilla glandulosa Lindl. & 1 & 40 & 8.0 & 1 & 45 & 5.5 & 1 & 10 & 1.0 \\
\hline Potentilla gracilis Dougl. ex Hook. & 0 & 0 & 0 & 1 & 2 & 1.3 & 1 & 0 & 0.0 \\
\hline Senecio spp. L. & 1 & 10 & 2.0 & 1 & 0 & 0 & 1 & 0 & 0 \\
\hline Taraxacum officinale Weber ex Wiggers & 1 & 29 & 4.6 & 3 & 14 & 2.6 & 3 & 31 & 8.7 \\
\hline Vicia americana Muhl. & 0 & 0 & 0 & 1 & 83 & 25.2 & 1 & 72 & 26.5 \\
\hline ROCK & 4 & 1 & 0.3 & 7 & 8 & 3.1 & 7 & 9 & 3.1 \\
\hline BARE SOIL & 4 & 3 & 0.6 & 7 & 13 & 2.0 & 7 & 30 & 9.4 \\
\hline LITTER & 4 & 63 & 25.3 & 7 & 66 & 26.8 & 7 & 69 & 28.9 \\
\hline
\end{tabular}

tall forbs and shrubs while favoring the growth of native grasses and unpalatable forbs (U.S. Forest Service 1937, Nelson and Leege 1982, Wallmo and Regelin 1981) (Table 3). Indian paintbrush in particular was harmed by mule deer herbivory. The addition of livestock, primarily cattle, significantly reduced the native grass cover at most sites, while introduced grasses and bare soil increased. It is clear that the combined level of ungulate use at all sites has not only altered the age structure of aspen stands but also altered understory species composition. It is equally clear that wildlife can dramatically affect the structure of aspen communities. Earlier open-range grazing studies have reported similar findings (Baker 1925, Weatherill and Keith 1969, Julander and Low 1976, Mueggler 1988, Smith et al. 1972).
Numerous hummingbirds were observed feeding on Indian paintbrush inside the total-exclusion area at the Hancock exclosure, but not inside the livestock-exclusion area or on outside plots. Thus, grazinginduced reduction of this flowering forb alone may have major effects on species not normally considered in range-wildlife studies. 


\section{Other Aspen Exclosure Studies}

Aspen exclosure studies throughout the western United States and Canada depict similar findings. Coles (1965) and Mueggler and Bartos (1977) report similar results in central Utah. Kay (1990) measured 14 aspen exclosures in the Yellowstone Ecosystem where elk are the major herbivore. He found that all protected stands regenerated and developed multi-aged stands and that protection completely altered the composition of the undergrowth: shrubs and palatable forbs dominated inside the exclosures, whereas non-native grasses resistant to grazing dominated outside. In 3 out of 4 exclosures in Colorado's Rocky Mountain National Park, where deer and elk are the primary herbivores, aspen developed multi-aged stands while areas outside did not (Hess 1993, Baker et al. 1997). In South Dakota, aspen in Custer State Park expanded into grasslands where wildlife were excluded (Hoffman and Alexander 1987), and aspen in Wind Cave National Park develop multi-size class stands after exclusion of wild ungulates (Kay 1990).

From study of 4 exclosures in Alberta's Elk Island National Park where elk and moose are the major herbivores, Milner (1977) concluded that not only was aspen regeneration restricted by browsing, but palatable shrubs were more abundant under protection. Trottier and Fehr (1982), evaluating exclosures in Canada's Banff National Park, concluded that aspen regeneration was limited by elk browsing and that protected plots had both greater shrub density and more diverse height than the unprotected plots. Comparing repeat photographs taken of an exclosure (after 50 years protection) near Banff, Kay et al. (1994) observed that a dense multi-aged aspen stand had grown up inside the exclosure while no aspen stems had regenerated successfully outside. These same authors also reported that aspen regenerated successfully where protected for approximately 10-years within the game-proof fenced Trans Canada Highway right-of-way through Banff's lower Bow Valley, but did not where elk were free to browse.

The consensus of all of these studies is that deer and elk can significantly hinder aspen regeneration and change understory species composition. Moreover, livestock use has an additive negative effect on aspen regeneration and understory composition. Excessive use by wildlife tends to reduce woody species and palatable forbs. Utilization by mule deer favors native grasses. Excessive elk use has a negative effect on grasslands because elk utilize a broader array of forages than deer (Nelson and Leege 1982). Excessive use by cattle also tends to reduce the abundance of native grasses and increase the amount of non-native species and bare soil.

\section{Climate Change}

The exclosures also demonstrate that climatic variation has had little effect on reproduction in aspen communities compared to that imposed by ungulates. Since the exclosure fence usually bisects a single aspen clone, differences between protected and open areas cannot be a product of either genetics or climate. The more abundant vegetation inside the exclosures, especially on total-exclusion plots, alters the microclimate, but that is an incorporated variable caused by the plant's response to the elimination of ungulate browsing, not the cause of the vegetation's response. Such microclimatic conditions would prevail in any aspen stand not subject to heavy ungulate use, whether in an exclosure or not.

If climatic variation is having an overriding effect on aspen community dynamics as proposed by others (Romme et al. 1995), we would expect aspen inside exclosures in south-central Utah to show signs of stress, especially since many of the exclosures are situated at the lower elevation of aspen or at grassland-aspen ecotones. However, no signs of physiological stress were observed during this study. In fact, the area occupied by aspen has increased inside exclosures at the expense of grasslands (Fig. 3). Baker et al. (1997) reported no correlation between climatic variation and aspen regeneration, while Kay (1990) reported that enclosed aspen in the Yellowstone Ecosystem replaced grasslands even on south-facing hillsides. White et al. (1998) and Kay (1997b) similarly reported no correlation between climate and aspen regeneration in the Canadian Rockies.

\section{Conclusions}

1. Browsing by native and domestic ungulates has hindered aspen regeneration throughout south-central Utah.

2. Aspen need not always be burned or clear-cut to regenerate successfully.

3. Wild ungulates, primarily mule deer, can have a major effect on aspen stem dynamics and understory composition.

4. Livestock grazing, as historically practiced in southern Utah, has had widespread effects on aspen communities, including changes in understory species composition.
5. Combined wildlife-livestock use most severely alters aspen community dynamics.

6. Aspen stands in the Rocky Mountain west dominated by old or single-age trees are most likely a product of excessive ungulate browsing.

7. Managers should quantify the level of ungulate herbivory before treating aspen stands with fire or cutting, because developing suckers may be subject to repeated browsing. If ungulate browsing is excessive, treatment of aspen stands may only hasten their demise.

\section{Literature Cited}

Baker, F.S. 1925. Aspen in the central Rocky Mountain region. USDA Agr. Bull. No. 1291.

Baker, W.L., J.A. Monroe, and A.E. Hessl. 1997. The effects of elk on aspen on the winter range in Rocky Mountain National Park. Ecography 20:155-165.

Bartos, D.L. and R.B. Campbell, Jr. 1998. Decline of aspen in the interior West-examples from Utah. Rangelands. 20:17-24.

Bartos, D.L. and W.F. Mueggler. 1981. Early succession in aspen communities following fires in western Wyoming. J. Range Manage. 34:315-318.

Bartos, D.L., J.K. Brown, and G.D. Booth. 1994. Twelve years biomass response in aspen communities following fire. J. Range Manage. 47:79-83.

Coles, F.H. 1965. The effects of big game and cattle grazing on aspen regeneration. M.S. Thesis, Brigham Young Univ., Provo, Utah.

Daubenmire, R. 1959. A canopy-coverage method of vegetational analysis.Northwest Sci. 33:43-64.

Despain, D.G., D. Houston, M. Meagher, and P. Schullery. 1986. Wildlife in transition: Man and nature on Yellowstone's northern range. Roberts Rinehart Inc., Boulder, Colo.

Hess, K. Jr. 1993. Rocky times in Rocky Mountain National Park: An unnatural history. University Press of Colorado, Niwot, Colo.

Hoffman, G.R. and R.A. Alexander. 1987. Forest vegetation of the Black Hills National Forest of South Dakota and Wyoming: A habitat type classification. USDA Forest Serv. Res. Paper RM-276. Fort Collins, Colo.

Houston, D.B. 1973. Wild fires in northern Yellowstone National Park. Ecol. 54:1111-1117.

Jones, J.R. and G.A. Schier. 1985. Growth pp. 19-24 In: Debyle, N.V. and R.P. Winokur eds. Aspen: Ecology and Management in the Western United States. U.S. Forest Service Gen. Tech. Rep. RM119. $382 \mathrm{pp}$.

Julander, O. and J.B. Low. 1976. A historical account and present status of the mule deer in the West. p. 3-19. In: Workman, G.W. and J.B. Low, (eds.), Mule deer decline in the West: A symposium. Utah State Univ. Agr. Exp. Sta., Logan, Utah. 
Kay, C.E. 1990. Yellowstone's northern elk herd: A critical evaluation of the "natural regulation" paradigm. Ph.D. Diss., Utah State Univ., Logan, Utah.

Kay, C.E. 1997a. Is aspen doomed? J. Forest. 95:4-11.

Kay, C.E. 1997b. The condition and trend of aspen, Populus tremuloides, in Kootenay and Yoho National Parks: Implications for ecological integrity. Canad. Field-Nat. 111:607-616.

Kay, C.E., and C.W. White. 1995. Long-term ecosystem states and processes in the central Canadian Rockies: A new perspective on ecological integrity and ecosystem management. p. 119-132. In: Linn, R.M.,( ed.) Sustainable society and protected areas. The George Wright Society, Hancock, Mich.

Kay, C.E., B. Patton, and C. White. 1994. Assessment of long-term terrestrial ecosystem states and processes in Banff National Park and the Central Canadian Rockies. Resource Conservation, Parks Canada, Banff National Park, Banff, Alberta.

Krebill, R.G. 1972. Mortality of aspen on the Gros Ventre elk winter range. USDA Forest. Serv. Res. Paper INT-129. Ogden, Utah.

Laycock, W.A. 1969. Exclosures and natural areas on rangelands in Utah. USDA For. Serv. Res. Paper INT-62. Ogden, Utah.

Laycock, W.A. 1975. Rangeland reference areas. Soc. for Range Manage., Range Sci. Series 3.

McDonough, W.T. 1979. Quaking aspen seed germination and early seedling growth. USDA Forest Serv. Res. Paper INT-234. Ogden, Utah.

Milner, B.J. 1977. Vegetation analysis of ungulate range exclosures, Elk Island National Park. Canadian Wildlife Serv., Edmonton, Alberta.
Mueggler, W.F. 1988. Aspen community types of the Intermountain region. USDA Forest. Serv. Gen. Tech. Rep. INT-250. Ogden, Utah. Mueggler, W.F. 1989. Age distribution and reproduction of aspen stands in the Intermountain Region. West. J. Appl. Forest. 4:41-45.

Mueggler, W.F. and D.L. Bartos. 1977. Grindstone Flat and Big Flat exclosures-a 41-year record of changes in clearcut aspen communities. USDA Forest Serv. Res. Paper INT-195. Ogden, Utah.

Nelson, J.R. and T.A. Leege. 1982. Nutritional requirements and food habits. p. 323-367. In: Thomas, J.S. and D.E. Toweill, (eds.), Elk of North America: Ecology and management. Stackpole Books, Harrisburg, Penn.

Olmsted, C.E. 1979. The ecology of aspen with reference to utilization by large herbivores in Rocky Mountain National Park. p. 89-97. In: Boyce, M.S., and L.D. Hayden-Wing, (eds.), North American elk: Ecology, behavior, and management. Univ. of Wyoming, Laramie, Wyo.

Romme, W.H., M.G. Turner, L.L. Wallace, and J.S. Walker. 1995. Aspen, elk, and fire in northern Yellowstone National Park. Ecol. 76:2097-2106.

Sampson, A.W. 1919. Effect of grazing upon aspen reproduction. USDA Bull. No.741.

Shepperd W.D. and F.W. Smith. 1993. The role of near-surface lateral roots in the life cycle of aspen in the central Rocky Mountains. For. Ecol. and Manage. 61:157-170.

Shepperd, W.D. and M.L. Fairweather. 1994. Impact of large ungulates in restoration of aspen communities in a southwestern ponderosa pine ecosystem. p. 344-347. In: Covington, W.S., and L.F. DeBano, (eds.), Sustainable ecological systems: Implementing an ecological approach to land management. USDA Forest Serv. Gen. Tech. Rep. RM-247. Fort Collins, Colo.
Smith, A.D., P.A. Lucas, C.O. Baker, and G.W. Scotter. 1972. The effects of deer and domestic livestock on aspen regeneration in Utah. Utah Division of Wildlife Resources Pub. 72-1. Salt Lake City, Utah.

Sokal, R.R. and F.J. Rohlf. 1981. Biometry: The principles and practice of statistics in biological research. 2nd ed. W.H. Freeman and Co., San Francisco, Calif.

Trottier, G.C. and A. Fehr. 1982. Re-evaluation of four range exclosures in Banff National Park, 1981. Canadian Wildlife Service, Edmonton, Alberta.

U.S. Forest Service. 1937. Range plant handbook. USDA, Forest Service, Washington, D.C. $841 \mathrm{pp}$

U.S. Forest Service. 1995. Environmental assessment for revised east slope cattle allotment management. Dixie National Forest, Teasdale, Utah.

Wallmo, O.C., and W. L. Regelin. 1981. Rocky mountain and intermountain habitats. Part 1. Food habits and nutrition. pp. 387-398 in Wallmo, O.C., ed. Mule and blacktailed deer of North America. Univ. of Nebraska Press, Lincoln, Nebr. 605 pp.

Weatherill, R.G. and L.B. Keith. 1969. The effect of livestock grazing on an aspen forest community. Alberta Dept. of Lands and Forests, Fish and Wildlife Div. Tech. Bull. No. 1. Calgary, Alberta.

White, C.A., C.E. Olmstead, and C.E. Kay. 1998. Aspen, elk, and fire in the Rocky Mountain national parks of North America. Wildl. Soc. Bull. 26:449-462.

Young, S. 1956. Survey and evaluation of big game exclosures in Utah. Utah State Dept. of Fish and Game, Federal Aid Division, Dept. Inform. Bull. No. 24. Salt Lake City, Utah. 